\title{
Kamerás megfigyelés, biztonság és szabadságjogok
}

A XVIII. századtól kezdődően az egyén annak köszönhetően lett engedelmes, hogy zárt helyeken (iskola, kaszárnya, üzem, kórház, börtön) azonosíthatóvá tették, s tudta, hogy figyelik. Növekvő mobilitása, s köztereken (repülőtereken, hypermarketekben) részlegessé és anonimmá váló identitása következtében a régi fegyelem az 50-es évektől veszített hatékonyságából. Napjainkban a kamerás megfigyelés a láthatóság tudatos és állandó állapotát hozhatja létre, biztosítva a hatalom automatikus működését. E viszonyt magába építve az egyén részt vesz önmaga alattvalóvá tételében.

\section{Szerzői információ:}

\section{André Vitalis}

A Bordeaux-i Michel de Montaigne Egyetemen az információ és a kommunikáció tudományainak oktatója, valamint a Médiakutató Központ vezetôje.

Szakértôként dolgozott az Informatika és Szabadságjogok Nemzeti Bizottságánál, az Általános Tervbiztosságnál és az Európa Tanácsnál. Számos múvet, kutatási jelentést és szakcikket publikált a média és az új technológiák szocio-politikai hátterével kapcsolatosan.

Fóbb publikációi: Informatika, hatalom és szabadságjogok, Economica, 1981, 1988; Telematika a városban, Service de la prospective DGT, 1983; A szokások szocio-politikájához (T. Vedellel), Association Descartes, 1993; Új technológia, új szabályozás? (E. Heilmannal), IHESI/CNRS, 1996. Számos vitafórumot szervezett, amelyek eredményeit publikálták, például: a média világméretû elterjedésérốl: Egy színlelt állampolgárság felé, Apogée/PUF; a média hatalmáról: Média, hatalom és demokrácia, Apogée/PUF; és a magánszféra kitárásáról: Magánélet a média korában, PUB.

Így hivatkozzon erre a cikkre:

Vitalis, André. „Kamerás megfigyelés, biztonság és szabadságjogok”. Információs Társadalom II, 1. szám (2002): 56-67. https://dx.doi.org/10.22503/inftars.II.2002.1.4

A folyóiratban közölt müvek a Creative Commons Nevezd meg! - Ne add el! - Így add tovább! 4.0 Nemzetközi Licenc feltételeinek megfelelöen használhatók. 
André Vitalis ${ }^{1}$

\section{Kamerás megfigyelés, biztonság és szabadságjogok²}

A nyugati nagyvárosok lakóit manapság sok száz elektronikus szem figyeli nap mint nap. Kiszámolták, hogy egy átlagos londonit egy átlagos napon legalább 300-szor filmez le mintegy 30 különböző videohálózat. A kamerás megfigyelés általánossá válása - jobban, mint a számítógépes nyilvántartások '70-es évekbeli elterjedése - mintha Orwell világába vezetne bennünket, ahol a képernyôkön már a legkisebb mozdulatot is kémlelik.

Már nem 1984-ben vagyunk, és még kevésbé „1984” zsarnoki és központi ellenôrzésû világában. Már nem Big Brother, hanem felügyelők sokasága figyel minket. A technika töretlen fejlődése - a kínálat bővülésével és a készülékek miniatürizálódásával - nagy mértékben befolyásolta a megfigyelés elterjedését. Az interneten elszaporodtak a webkamerák, amelyek folyamatosan készítik a felvételeket, és amelyek bármely netezốt egy földalatti parkoló vagy a világ másik végén található bevásárlóközpont megfigyelőjévé varázsolhatnak. Egyébként a kamerás megfigyelést a legtöbb emberi szolgáltatásnak, nem pedig elviselhetetlen korlátozásnak vagy erôszakos eljárásnak tartja. A bűnözés és durvaság elburjánzásának korában a kamerás megfigyelés az emberek növekvő biztonságérzet-hiányát próbálja orvosolni.

A videokamerák jelenléte szükséges tehát, de azért szembe kell nézni a technobiztonság veszélyeivel is. A kamerák - fôleg, ha neveket tartalmazó információkat is rögzítenek - sérthetik az egyének azon jogát, hogy szabadon közlekedhessenek a köztereken, anélkül, hogy azonosítanák és megfigyelnék óket. A biztonság érdekében rögzített képeket bármikor felhasználhatják más, illegális célokra is. Ezen körülmények közt magától értetődik, hogy használatuk szabályozására több szabadságjogokat védő elv is megfogalmazódott: például az 1995. október 24-i európai direktíva vagy egyes nemzeti törvények. Egyensúlyt kell teremteni a biztonságra való törekvés, valamint a személyes adatok és autonómia védelme között. Ennek érdekében át kell gondolni, hogy milyen megfigyelőrendszert alkalmazunk, és hogy a képnek, mint személyes adatnak milyen sajátosságai vannak.

\section{A kamerás megfigyelés általánossá válása}

Az elmúlt 30 évben a kamerás megfigyelés szükséges és bizonyos esetekben elengedhetetlen módszerré vált. A '70-es évek elején azért szerelték fel az elsố rendszereket, hogy segítsék a nagy agglomerációk kritikus közlekedési pontjainak irányítását, és hogy hatékonyan lehessen fellépni az agresszió, valamint a bankokban és luxusüzletekben elkövetett lopások ellen. A kamerák segítségével folyamatosan nyomon lehet követni egy-egy terület eseményeit a megfigyelőállomásról, így incidens esetén azonnal közbe lehet lépni, és az eseményekrôl felvétel is készül. A '80-as években a 
személyek és javak védelme érdekében a megfigyelő rendszerek megjelentek a tömegközlekedésben, az üzletekben, a munkahelyeken, a szabadidóközpontokban és a középületek környékén. A '90-es évek elején kamerákat helyeztek el a közutakon, illetve bizonyos városok utcáin, s ez még egy lépést jelentett a megfigyelés általánossá válása felé.

A kamerás megfigyelés manapság a városi élet mindennapjainak része, elég, ha arra gondolunk, hogy hányféle helyen szereltek fel kamerákat: pályaudvarokon, üzletekben, utcákon, parkolókban. A legkisebb mozdulatot is meg lehet manapság figyelni távolból, egy tévéképernyőn. A köz- és magánterületeken elhelyezett több ezer kamera az internet segítségével mindent lát és felügyel. Az Egyesült Királyságban az önkormányzatok 85\%-a hozott létre városi kamerás megfigyelőrendszert, 1999-ben a brit belügyminiszter az egész országot (autóbuszokat, magánterületeket, pályaudvarokat és közparkolókat) behálózó rendszer kiépítésére tett ígéretet. A múködtetők szerint Franciaországban egymillió rendszer létezik, ebből 150.000 a közterületeken, és évente 25.000 - 30.000 új berendezést szerelnek fel. A becslések szerint a hipermarketek 100\%-a, a nagyvállalatok és közintézmények 80\%-a, a szállodák, kórházak és sportlétesítménnyek $10 \%$-a van megfigyelő-kamerákkal ellátva.

A technikai fejlődés és a csökkenő árak mindinkább vonzóvá teszik a beruházást. A kamerák valóban egyre hatékonyabbak: a legfejlettebb kamerák közül néhány 360 fokos szögben képes egy adott területet filmezni, más kamerák éjjel is kiválóan múködnek, vagy zoomjukkal 100 méter távolságból is el tudnak olvasni egy újságot. Egyébként a digitális eljárások fejlődésének köszönhetően újfajta, „intelligens” rendszerek láttak napvilágot. Ezek a felvett képet olyan szoftverekkel dolgozzák fel, amelyek képesek a rendellenes történéseket észlelni a kamera látómezejében: egy ajtó kinyílása, gyanús füst, váratlan mozdulat... Ugyanígy néhány hipermarketben az elhelyezett kamerák segítségével egy szoftver méri, hogy a vásárlók mennyi idôt töltenek a polcok előtt, és így negyedóráról negyedórára ki lehet számolni, hogy hány pénztárt kell megnyitni.

A személyek és a javak védelme indokolja a megfigyelőrendszerek elterjedését, mely egyben a biztonság megerősítésére való általános igényt is kielégíti. A ' 80 -as években ugrásszerúen megnôtt a városokban az erőszakos cselekedetek, lopások, betörések és különböző agressziók (rongálás, falfirkák, agresszív magatartás) száma. Franciaországban a rendôrség által nyilvántartásba vett bűntettek száma a ' 90 -es években átlagosan 4-szer volt magasabb, mint a "60-as években, és majdnem háromszor magasabb, mint a '80-as évek elején. Ezzel párhuzamosan a hagyományos intézményi fellépés eredménytelenségének lehetünk tanúi. A rendőrségi statisztikákból kitúnik, hogy a felderített esetek száma egyre csökken. Amíg a rendốrség 1950-ben a lopásos esetek felét felderítette, ez az arány 1993-ban már csak 12,5\% volt. A hagyományos rendốrség kis hatékonysága, valamint a növekvő biztonságérzet-hiány új módszerek keresését tette szükségessé. Ezzel magyarázható, hogy egyre nagyobb az igény a magán és önkormányzati biztonsági szolgáltatásokra és az olyan berendezésekre, mint a kamerák, még ha ezeket nem is mindig a bünözés szempontjából legveszélyesebb területeken szerelik fel, hanem ott, ahol a legtöbb nyereséges üzlet található. A biztonságérzet hiányával magyarázható, hogy a lakosság nagy része szívesen fogadja ezeket az új technológiákat, melyeket a biztonság és a bűnüldözés elleni fellépés eszközeként tartanak számon. Egy Nagy-Britanniában végzett felmérés szerint a lakos- 
ság 95\%-a kedvezően fogadja a kamerás megfigyelést, melyet nem a magánéletbe való beavatkozásnak, hanem „biztonságos védelemnek” tart. Egy felmérés azonban, amelyet 1996-ban Franciaországban készítettek 1000 fôs reprezentatív mintán azt mutatja, hogy a társadalmi elfogadottság változhat az alkalmazási terület szerint. Amíg az emberek csupán 9\%-a gondolja, hogy a parkolókban és az üzletekben elhelyezett megfigyelố kamerák sértik a privát szférát, az arány érezhetôen nő a belvárosokban található kamerákat illetően. Az emberek 51\%-a súlyos jogsértésnek tartja, ha a közterületeken felvett képeket a tudta nélkül felhasználják.

A technobiztonságra valóban szükség van, de a kínálat talán még inkább közrejátszott a rendszerek elterjedésében. A tervezôk szerint a termékek tökéletesedésével és miniatürizálódásával a kínálat meghatározó szerepre tett szert, „A technika megteremtette a szükségleteket.” Egyszerúbb és olcsóbb termékeivel a kamerás megfigyelés piaca egyre több felhasználóval bővül, melyből hatalmas hasznot húznak a biztonságtechnikai nagyvállalatok. Olyan kamerákat is kifejlesztettek, melyek kábelrendszerekkel múködnek együtt; a megfigyelés bevezetése alkalmat teremt a bekábelezett városòknak arra, hogy nyereségessé tegyék hálózatukat. Új szolgáltatás a lakóházaknak kínált kamera: az építô- és szolgáltató vállalatok olyan rendszereket ajánlanak, melyekkel a lakók felügyelhetik házuk bejáratát. Nem szabad alábecsülnünk azt a tényt sem, hogy egyes helyi képviselők választási sikert remélnek a technobiztonság fejlesztésétôl. Néhány város könnyelmúen el is kötelezte magát a kamerás megfigyelés mellett, anélkül azonban, hogy előzetesen felmérte volna az igényeket.

\section{A kamerás megfigyelés nem minden esetben hatékony}

A kamerás megfigyelést sok támadás éri, hiszen biztonsági eszközként való hatékonysága megkérdőjelezhetô, és az egyéni szabadságjogok védelmét sem biztosítja.

Számos példa bizonyítja, hogy a videó fontos szerepet játszik a biztonság javításában. 1993-ban például egy megfigyelố-kamera segítségével tartóztattak le Liverpoolban két gyilkos gyereket. A kamerákkal felszerelt bankokban a tolvajok 50\%-át sikerül beazonosítani és két éven belül letartóztatni. A videónak köszönhetően a párizsi metróban az incidensek 83\%-át észlelték és 36\%-kal nôtt az igazoltatások száma. Egy áruház vezetôje szerint a kamerák felszerelése óta az ismeretlen eredetú leltárhiány kétharmaddal esett vissza. Egy 10.000 lakosú angol településen - ahol hat kamera figyeli a városközpontot - a búncselekmények száma az 1991-es 137-rốl 37-re csökkent 1992-ben.

Bőséggel találunk még hasonló példákat, de a kamerás megfigyelés mégsem mindig hatékony. Néhány esetben a megfigyelés eredménye kiábrándító. Ez főleg annak köszönhetô, hogy nem elemzik kellőképp az elérendő célokat és nem megfelelô felszerelést alkalmaznak. A párizsi metróban rengeteg kamerát helyeztek el, a felvételek mégsem hoztak eredményt a terrorizmus elleni harcban. Franciaország egyik legjobban felkamerázott városában, a Párizs környéki Levallois-Perret-ben, amelynek utcáit 86 kamera figyeli, folyamatosan nő a bűncselekmények, leginkább az autórongálások és lopások száma. Az Egyesült Államok több nagyvárosában is rossz tapasztalatokra tettek szert az utcai kamerás megfigyeléssel kapcsolatban. Atlantic Cityben és Miamiban leszerelték a berendezéseket, mert ezek segítségével nem sikerült sen- 
kit sem letartóztatni. Az is igaz, hogy a videofelvétel csupán az első eleme egy háromlépcsős munkafolyamatnak. A következő lépcsőkrốl van szó: jelzés, diagnózis és beavatkozás. A diagnosztizálás annyit jelent, hogy (a legrövidebb idô alatt) értelmeznek és értékeljenek egy adott területen történt eseményt. De ennek csak akkor van értelme, ha a következố láncszem is - például egy bevethetố alakulat - ,rendelkezésre áll. Márpedig ez nem mindig adott. Egy büncselekmény azonnali észlelése nem azonos a beavatkozással és a tettes letartóztatásával. A megfigyelő́k követni tudják az eseményeket, de csupán távolból, tehetetlenül. Csak a helyszínre érkezố járőrök tudnak közbelépni.

Még azokban az esetekben is, amikor a megfigyelés hatékony, fel kell tennünk a következő kérdést: lehet, hogy a technobiztonsági eszközök csak a megfigyelt területekről szorítják ki az erőszakos cselekedeteket, és a bủnözők tovább garázdálkodnak a kamerák látómezején kívül? A berendezések biztonságossá teszik a felszínt, de a búnözés folytatódik a föld alatt. Emelkedett például a földalatti parkolókban elkövetett bưncselekmények száma. Alpes-Maritimes megyében háromszor magasabb a bủnözési ráta, mint a szomszédos Monacoban, melyet zoommal felszerelt kamerahálózat övez. Egyre nőnek a különbségek, félő, hogy a jövőben kétfajta övezet alakul ki: az egyik a technikai eszközöknek köszönhetôen teljesen biztonságos, a másik elhanyagolt, veszélyes. Éppen ebbôl a szempontból kelt aggodalmat az „erôdítmény-városok”-nak nevezett jelenség. Ezekben az „erôdítményekben”az őrök és a kamerák csak a házban lakókat engedik ki- és belépni. Az Egyesült Államokban ma 8 millió ember él - 20.000 közösségben - ilyen védett terekben. Az ország déli részén élô gazdagok így védekeznek az óket körülvevố szegénység ellen. De a különbözô technológiák csak helyileg orvosolják a biztonság hiányát, a jelenség legmélyebb - elsősorban politikai és szociális - okai továbbra is fennmaradnak.

Noha a kamerás megfigyelést általában nagyon körültekintően alkalmazzák, mégis bizalmatlanság övezte már a kezdetektôl. 1980-ban egy francia képviselő írásos beadványban fordult az igazságügyi miniszterhez, hogy felhívja figyelmét arra, hogy a bankok és bevásárlóközpontok pénztárainál elhelyezett felvevôkészülékek sértik a személyiségi jogokat. Az elektronikus megfigyelés a 80 -as évek végére vált általánossá, csak ekkor törtek igazán felszínre az aggodalmak, és csak ekkor merült fel az a kérdés, hogy valóban helyes-e ezeknek az eszközöknek az alkalmazása. A közutakon és a városközpontokban elhelyezett, biztonsági célokat szolgáló kamerák sértik a lakóknak azt az alapvetố jogát, hogy szabadon közlekedhessenek a közterületeken anélkül, hogy figyelnék óket. A városokban felállított rendszerek ugyan nagy sikert könyvelnek el, de tiltakozások is akadnak. A polgárok számos helyen a létezó rendszerek megszúntetését, vagy a készülő terv elvetését követelik.

Előfordul, hogy a kisvárosokban - az önkormányzatok kérdésére válaszolva - a választópolgárok mondják ki azt a többségi véleményt, hogy nem szeretnének kamerákat látni a köztereken. 1990-ben a francia közigazgatási bíró az arányosság elvére hivatkozva érvénytelenítette egy városi képviselôtestület döntését, mely arról rendelkezett, hogy a városban olyan kamerás megfigyelőrendszert hoznak létre, amellyel a város egész területét ellenőrizni lehet. Szükség esetén a felvételeket megórizték volna. A bíró szerint „a kamerák felszerelése és állandó múködtetésük súlyosan sérti a személyhez füződő jogokat, nevezetesen a magánélethez és a képmáshoz való jogot.” A kamerák felszerelését nem indokolhatja sem bírósági felhatalmazás, sem a közérdek, 
sem a közúti szabálysértések, a javak, valamint a személyek elleni támadások észlelésére való törekvés. Ez egy alapvetố arányosság-elv, mely egyensúlyt teremt a biztonság, valamint az személyi szabadságjogok megőrzése közt. A demokrácia alapkövét jelentik az egyéni szabadságjogok, ezeket csak akkor lehet például képek készítésével megsérteni, ha a képfelvétel célja ezt indokolja. A szabadságjogok megsértése jogos lehet a kevéssé biztonságos területeken, de korántsem mindenhol. Egy belga szakközépiskolában még a mosdóban is helyeztek el kamerákat, hogy a dohányzókat lebuktassák. A hipermarketekben rejtett kamerák figyelik a próbafülkéket, hogy a ruhaosztályon csökkentsék a lopásokat. Azt is megállapították, hogy a közutakat, illetve a hipermarketek bejáratát ellenőrző kamerákkal a szomszédos házak belseje is megfigyelhető.

A biztonság érdekében felszerelt kamerákat más célra is fel lehet használni. A pekingi Tienanmen téren elhelyezett kamerák segítségével például több „ellenforradalmárt” azonosítottak és tartóztattak le. Számos példa van arra is, hogy a kamerás megfigyelőrendszerek képeit sztrájkolók azonosítására használták fel. Az is elôfordulhat, hogy rendőrségi felvételekból készült videokazetta kerül forgalomba (ez történt például Angliában). A megfigyelőrendszerek több funkcióval rendelkeznek, és a használat során újabb alkalmazási területek is felmerülhetnek. Tapasztalhatjuk például, hogy a bevásárlóközpontokban felállított kamerák, melyek a vásárlókat figyelik a lopások észlelése érdekében, az alkalmazottakat is ellenőrzik, bár ezt csak ritkán vallják be. A lopások elleni védekezés átalakulhat munka- és hatékonyságellenőrzéssé: ezt bizonyítja számos elbocsátási per, amelyben a videofelvételek terhelô bizonyítékul szolgálnak. Szép jövő elé néz a videóval ellenőrzött munka. Több biztonságtechnikai vállalat vezetôje állítja, hogy manapság a javak védelme mellett az alkalmazottak felügyelete (a belsố lopások és hiányzások kiszúrése) és a munkaminôség ellenốrzése motiválja leginkább ügyfeleiket a beruházáskor.

A kamerák segítségével azt is lehet elemezni, hogy miképp viselkednek a vásárlók egy üzlet különbözô osztályain. Tanulmányokat lehet készíteni a különbözố fogyasztói magatartásokról a vásárlók hatékonyabb megcélzása érdekében. Az ilyen elemzések valóban nagyon hasznosak, lehetővé teszik az áruk elhelyezésének tökéletesítését, és a leginkább hasznot hozó vásárlási útvonal kidolgozását. A legtöbb pénzt költő vásárlók filmezésével ki lehet alakítani a jó vásárló profilját. A tolvajokról készült képek segítségével pedig nyilvántartásba lehet venni a gyanús embereket és a visszaesô bűnözốket. A technika fejlődése nagymértékben hozzájárul az alkalmazási területek bővüléséhez. A jelenlegi kutatások célja egy olyan szoftver kifejlesztése, mely egy többszereplős felvételen automatikusan felismeri egy keresett személy arcát.

\section{Fegyelmezés és ellenőrzés}

Számos - köztereken és üzletekben elhelyezett - berendezést vizsgáltak meg Franciaországban, és azt állapították meg, hogy a kamerás megfigyelésnek két jól elkülöníthetố típusa van. Az egyik célja a fegyelmezés, ez arra ösztönzi az embereket, hogy az elvárt módon viselkedjenek. A másik célja az ellenôrzés, ez csak akkor lép igazán múködésbe, ha nem megfelelổ viselkedést észlel. Ez utóbbi esetben a biztonsági munkafolyamat mindhárom eleme jól szervezett. 
E két fô típuson kívül természetesen léteznek vegyes rendszerek is.

Az első típusú megfigyelés a régi fegyelmezési módok örököse. Több, mint 300 éven keresztül az önuralom és az önfegyelem biztosította az erkölcsösséget és az emberi viselkedés kiszámíthatóságát. Norbert Elias írta meg, hogy a XVII. és XVIII. századi udvari társadalmak kialakulása miképp küszöbölte ki az erôszakot, s hozott létre az egész társadalomban érvényesülő önuralomon és önkorlátozáson alapuló új magatartásformákat. Norbert Elias gondolatait Michel Foucault folytatta, szerinte a panoptikus és fegyelmezố mechanizmusok teremtették meg a XVIII. század végétôl az ideálisan viselkedő egyént. A társadalom tagjai annak köszönhetően lettek engedelmesek és hasznosak, hogy zárt helyeken (iskola, kaszárnya, gyár, kórház, börtön) tartózkodtak, beazonosíthatóan. A bezárt egyén, aki tudja, hogy figyelik, tudomásul veszi a hatalom elvárásait, és önkéntelenül ezek szerint viselkedik. A Bentham által feltárt panoptikus társadalmi struktúra lényege az, hogy a bezárt egyénben „tudatosítják a megfigyelés tényét, amely biztosítja a hatalom automatikus múködését. Azt kell elérni, hogy a megfigyelés mindig elérje célját, még akkor is, ha az ellenőrzés valójában nem folyamatos; hogy a hatalomnak ne kelljen állandóan felügyelnie; hogy a panoptikus társadalmi struktúra mechanizmusa olyan hatalmat hozzon létre, amely független attól, aki gyakorolja. Az egyén átveszi a hatalmat, és saját magának engedelmeskedik.

Az 50-es évektől kezdődően a régi fegyelmezési módok vesztettek hatékonyságukból, errôl tanúskodik az erôszakos cselekedetek, lopások, betörések elburjánzása. A zárt helyek a változások korát élik. Az egyén mobilitásának növekedésével csökken ezeknek a helyeknek a társadalom-összetartó és ellenőrző szerepe. A modern korban születtek meg - Marc Augé antropológus szóhasználata szerint - a „nem-helyek”, például a repülő́terek, bevásárlóközpontok, ahol csak a részleges és névtelen személyiség mutatkozik meg. Ebben a megváltozott helyzetben a videó megpróbálja korszerúsíteni a panoptikus és fegyelmezố rendszereket. Korábban csak a zárt helyeken alkalmazták a „figyelnek bennünket, de mi nem látjuk a megfigyelőket” elvet, mely ezentúl fontos szerepet játszik a nyílt helyeken is, melyeket az egyre inkább mobilis egyének látogatnak. Az egykori geometrikus megfigyelést felváltja az elektronikus megfigyelés, a kamerák látóterei megannyi panoptikont képeznek. „Amikor tudjuk, hogy kamerák figyelnek - mondja Paul Virilio -, akkor úgy viselkedünk, ahogy azt vélhetốen elvárják tôlünk, pedig talán épp senki sem ellenőrzi a képeket.” Az a fontos, hogy a kamerával megfigyelt egyén tudja, hogy figyelik. Ez a tudás teremti meg a fegyelmet, és készteti az egyént arra, hogy úgy viselkedjen, ahogy elvárják tóle. A panoptikus rendszer hatékonysága a „figyelnek bennünket, de mi nem látjuk a megfigyelő́ket” elvnek, de még inkább ezen elv tudatosításának köszönhetô. Ezért ez a fajta kamerás megfigyelés soha sem rejtett; vagy jól láthatóan helyezik el a kamerákat, vagy pedig nyíltan jelzik jelenlétüket a „Mosolyogjon, felvétel készül”-típusú feliratokkal. A közbelépés ennél a megfigyelési módnál nem elsôdleges fontosságú. A régi fegyelmezési módokhoz képest újdonság, hogy az új rendszerek a megfigyelt személyeknek biztonságot nyújtanak, ezért jogosságukat a legtöbben nem is vitatják. Bizonyos hálózatok lehetôvé teszik, hogy az egyén egyszerre legyen megfigyelő és megfigyelt. A lakóházakban elhelyezett kamerák filmezik a közös helyiségekben található személyeket, akiket a lakók is láthatnak monitorjaikon.

A kamerás megfigyelés második típusa új fajta ellenôrzést vezet be. Láttuk, hogy a fegyelmezést célul kitűző (elsố típusú) rendszerben az egyén saját magát sza- 
bályozza önkorlátozással és önuralommal. A technoellenôrzésnél erre nincs szükség, az egyénekről összegyújtött információknak köszönhetően. A rendszer információkat kezel és egy elvont, személytelen, automatikus, nagy részben láthatatlan és érthetetlen mechanizmussal cselekvésre tud késztetni. Az ellenőrzésre nem a kényszerítés, hanem a manipuláció, a távoli, láthatatlan irányítás jellemző. Az összegyújtött információk segítségével szabályozzák a társadalmat, minden helyzetben másképp. A nevelő célzatú megfigyelést, amely a megfigyelt személy részvételére épül, felváltja egy olyan rendszer, amelyben az egyén csak egy adathalmaz.

Az ellenőrzéstechnikák egyik legalapvetőbb jellemzője a láthatatlanság. A döntéshozatalt segítố adatok begyưjtése és elemzése az érintett személyek tudta nélkül történik, ennek a titkosságnak köszönhetô hatékonyságuk. A '70-es években a személyi adatokat számítógépes nyilvántartásba vették, s ettől kezdve olyan elemzéseket lehetett készíteni, amelyekről csak az adatkezelők tudtak (például a különböző piaci profilok kialakítása során). A mágneskártyák és a különbözó elektronikus eszközök növekvő használata lehetővé teszi, hogy nagy mennyiségű, neveket tartalmazó információt gyüjtsenek össze és elemezzenek titokban. Az elektronikus eszközökkel történő interakció soránrögzített információkat egyre titkosabban gyújtik össze, olyan eljárásoknak köszönhetően, melyek automatizálják az adatrögzítést. Például a „szabad kéz” nevü technológiával a felhasználónak nem kell bemutatnia mágneses személyazonosító kártyáját, elég, ha elmegy a leolvasó elốtt. Egyes szoftverek adatokat tudnak leolvasni a számítógépek merevlemezérôl, a felhasználó tudtán kívül. Ugyanez történik az interneten is: a szerver a netezők legkisebb mozdulatát is ellenőrizni tudja, engedély és előzetes figyelmeztetés nélkül. Az érzékelô-készülékek, nevezetesen a videofelvevő́k tovább növelik az egyének átlátszóságát, hiszen a képfelvétellel folyamatosan nyomon tudják követni őket. A biztonság megórzése gyors döntéshozatalt és közbelépést kíván. A leghatékonyabb rendszerekben a munkafolyamat három lépcsôje (jelzés, döntés, közbelépés) tökéletesen van megszervezve. Mindenfajta közbelépéshez ki van dolgozva a követendő eljárásmód. Ezek a rendszerek nagyon kifinomult eljárásokra képesek. A kamerák minden részletet meg tudnak figyelni és nehéz felfedezni ôket.

\section{Többjelentésű és manipulálható képek}

Az ellenőrzốkamera elôtt ülő felügyelôt nem önmagukban a személyek érdeklik, hanem az, ami ezekben a személyekben vagy viselkedésükben esetleg eltér az érvényben lévő normáktól. Például az, ha valaki extravagáns ruhát hord, vagy valamilyen etnikai kisebbséghez tartozik, esetleg sokat habozik az üzletben egy áru megvásárlása előtt, vagy éppen bukósisakot tart a kezében egy bankban. Jelenleg egy olyan szoftver van kifejlesztés alatt, mely elemzi és értékeli a felvett képeket, majd értesíti a biztonsági ôrt, ha rendellenes magatartást észlel. E szoftver hiányában - mely előreláthatóan 2005-ben lesz üzemkész - a gyanús elemek kiszûrése teljesen szubjektív módon történik. Azoknak az alkalmazottaknak, akik ezt a munkát végzik, nincs különösebb képzettségük. Értékeléseik és döntéseik nagyon különbözők lehetnek, ennek oka a képzetlenségben, a magán- és közszféra szabályainak sokféleségében, és a homogén erkölcsi értékrend hiányában keresendő. 
A videó, mint ellenőrző technológia legnagyobb újítása az, hogy újféle jelekkel ábrázolja az egyént. Az informatikai képmás, mely csak szövegszerû adatokból állt, a videó által rögzített képeknek köszönhetôen átalakul multimédiás képmássá. Ezentúl figyelembe kell venni ezen új átlátszóság új problémákat felvető sajátosságait. Az információ fogalma túl általános és elvont, elfedi a különbözó ábrázolásmódok közti különbségeket. A képnek kifejezetten nem ugyanazok az előnyei és hátrányai, mint a szövegszerü adatoknak.

Az olyan információ- és kommunikációelméletek, mint például a Palo Altoi iskolájé, a szemiológia és a mediológia, felhívták a figyelmet a jelhordozók és a jelek minőségének fontosságára. Charles Peirce jelelméletét követve háromfajta jelet különböztethetünk meg: az indexet, az ikont és a szimbólumot. Eme jelek különféleképp ábrázolnak. Az index az ábrázolt tárgy része, vagy szoros kapcsolatban van vele, ez utóbbira példa a hóban lévő lábnyom. Az ikon nem azonos az általa ábrázolt tárgygyal, de hasonlít rá, és e formaazonosság miatt sohasem önkényes. A szimbólum nem hasonlít az ábrázolt tárgyra, amellyel kapcsolata konvención alapszik. Ilyenek például a nyelvi jelek, melyeket meg kell tanulni, hiszen önkényesek. Az egyénekről gyüjtött jelek közt mindhárom ábrázolásmód megtalálható. Az elektronikus jelhordozókon hagyott nyomok indexjel típusú információja, a nyilvántartások rendezett adatainak szimbolikus információja és végül a videoképek - és a jövőben talán a hangok ikonikus, analóg (formaazonosságon alapuló), információja.

A valóságban természetesen nem lehet ennyire éles különbségeket tenni. Például az index információ kiegészítheti a nyilvántartások adatait, a képet pedig index és analóg információként is fel lehet fogni. De a fenti felosztás - korlátai ellenére kiemeli a különbözô ábrázolásmódok sajátságait, ami fontos, hiszen az egyes ábrázolásmódoknak más és más elônyei és hátrányai vannak. Mivel a képfelvétel jelenti az újdonságot, ki kell térnünk azokra a különbségekre, amelyek az analóg információ és a klasszikus nyilvántartások szimbólum-használó információja közt vannak. A két legfontosabb különbséget említjük meg. Az elsố az, hogy a szimbólum információt szelektálják és újracsoportosítják a nyilvántartásba vétel előtt, ezzel szemben a videokamera mindent felvesz, ami a látómezejébe kerül. Ebbôl adódik, hogy a felvétel olyan többletinformációt is tartalmaz, amire az eredeti cél eléréséhez nincs szükség. Például egy személyrôl készült kép, főleg, ha mozgókép, a személyazonosságon kívül egy sor más információt is közöl az adott emberról: arckifejezés és mimika, gesztikuláció, környezet, öltözködés, stb. Ez az információtöbblet annál inkább problémát okoz, minél inkább azonnali interpretáció tárgyát képezi, mivel a szöveggel szemben a kép természetébôl adódóan mindig többjelentésû. Az idôbeli eltávolodás hiánya felületes értelmezésekhez és elhamarkodott reakciókhoz vezethet. Igaz, hogy a jövőben szoftverek is segítséget nyújtanak majd bizonyos helyzetek kiszűrésében. Így például egyes szoftvereket arra fejlesztenek ki, hogy észleljék a gyanúsnak ítélt viselkedést. A szoftver egy kamera által rögzített képen azonosítja azt a személyt, akinek valamelyik mozdulata nem felel meg egy előre megírt forgatókönyvnek, így ez a személy elveszti a közlekedési eszközök és üzletek tömegében élvezett névtelenségét.

A szöveg és a kép közti második lényeges különbség a kép index- és analóg jel mivoltából adódik. Míg a szimbolikus információ természeténél fogva önkényes, az ikonikus jel a valóságot ábrázolja, áttétel nélkül. Mivel az ábrázolt tárgy lenyomata rajta van a film fényérzékeny rétegén, a videokép bizonyíték, amely a valóságról tanús- 
kodik. Nem is ábrázolásról, hanem inkább bemutatásról beszélhetünk. Mivel nem önkényes jel, a képnek nagy a bizonyító ereje. Az a tény, hogy a képet gép készíti iparszerűen, még inkább növeli hitelét. A gép - egy emberrel szemben - objektíven és automatikusan filmez látómezejében. A helytelen értelmezéseknek nemkívánatos következményei lehetnek. A képek digitalizációja lehetôvé teszi a hamisítást, a manipulációt és az utánzást. Még szimulálni is lehetne bizonyos eseményeket egy adott állítás bizonyítása érdekében, kimutatva valódiságát a látható képek pszeudo-nyilvánvalósága segítségével.

\section{Nélkülözhetetlen adatvédelem}

A kamerás megfigyelés jogosultsága azzal igazolható, hogy a biztonság megteremtése a célja. A biztonság a személyi szabadság alapja, továbbá alapvetô emberi jog is. Egy francia közmondás azt tartja, hogy „Aki nincs biztonságban, annak semmije sincs”. Márpedig az emberek nem élnek egyforma biztonságban. A technobiztonság eszközeit nem alkalmazzák mindenhol, s ez növelheti a társadalmi különbségeket és a kirekesztést. A városokban egymás mellett találhatók olyan negyedek, amelyek hiperbiztonságosak és kamerákkal vannak felszerelve, valamint olyanok, ahol virágzik a bûnözés és ahová a rendőrség sem meri betenni a lábát. Akárhogy is van, a megfigyelésnek mindig lesznek hibái és korlátai. A városban közlekedő egyén megfigyelése a szabadság nem mindig jogos korlátozása. Ráadásul tudjuk, hogy a búnözés elleni harc érdekében felszerelt kamerák az alkalmazottak és a vásárlók viselkedését is kémlelik.

A szabadságjogokat fenyegetố veszélyeket szem elốtt tartva szükségessé vált a kamerás megfigyelés korlátozása és használatának szabályozása. Fontos szerepet játszottak ebben az adatvédelmi bizottságok, melyekhez panaszok érkeztek és amelyek kapcsolatot tartottak azokkal az önkormányzatokkal és vállalatokkal, amelyek megfigyelő-hálózatot akartak kiépíteni. A veszély tudatában nagy erőfeszítéseket tettek annak érdekében, hogy mihamarabb alkalmazásra kerüljenek azok a személyi adatok védelmérôl szóló szabályok, amelyeket az Európa Tanács 1981-es Egyezménye és a legtöbb nemzeti jog is rögzít. 1994-ben Franciaországban az Informatikai és Szabadságjogi Bizottság (La Commission Nationale de l'Informatique et des Libertés CNIL) ajánlást fogalmazott meg a közterületeken és emberek által látogatott helyeken felállított kamerás megfigyelőrendszereket illetően. Ez a szöveg öt fó alapelvet rögzít. Tiszteletben kell tartani az arányosság elvét, tehát megfelelő egyensúlyt kell teremteni a biztonság megteremtésére való törekvés és a szabadságjogok védelme között. A kamerákat úgy kell elhelyezni, hogy a közintézmények bejárata ne legyen látható. A képeket csak abban az esetben szabad megőrizni, ha ez a személyek és javak védelmében történik. A képeket legfeljebb két hétig lehet megôrizni. Végül pedig: értesíteni kell az ügyfeleket a megfigyelés tényéról. A személyi adatok védelméról 1995-ben elfogadott európai direktíva a képeket és hangokat is beveszi (ugyanazon okból, mint a szövegszerú adatokat) a védelmet élvezó adatok közé. Ezeknek az információknak egyforma garanciát kell élvezniük, akár képről, hangról, akár szövegről van szó. A direktíva azt mondja ki tehát, hogy a kamerás megfigyelés során is be kell tartani a következô elveket: megfigyelt személyek elôzetes értesítése, adatvédelem, adatok titkos kezelése, adatmegőrzés idejének korlátozása. A '70-es években a számítógépes adatbázisok veszélyeinek kiküszöbölésére kidolgozott védő szabályok bi- 
zonyos esetekben nehezen alkalmazhatók, például a kamerás megfigyelés biztonsági célja, valamint az ikonikus jel sajátosságai miatt. A kamerás megfigyelés célja a biztonság hiányának felszámolása és a bűnözés elleni harc, ezért itt nehezebb egyensúlyt teremteni a társadalmi érdekek és a személyi szabadságjogok közt. Az európai direktíva csak a személyes használatra felállított megfigyelőrendszerekrôl rendelkezik, nem szól a közbiztonság, valamint az államvédelem érdekében kiépített hálózatokról. Ezekrôl a nemzeti törvények rendelkeznek. Ha az 1995. január 25-i, a közintézményekben, és az emberek által látogatott helyeken elhelyezett kamerákról rendelkezô, biztonságra vonatkozó francia törvényt megvizsgáljuk, láthatjuk, hogy a garanciák száma egyre csökken. A szöveg több pontja védi a személyi szabadságjogokat. Csak olyan helyen lehet hálózatokat kiépíteni, ahol „nagy az erôszakos cselekedetek és a lopások száma.” Az embereket „egyértelmúen és folyamatosan” értesíteni kell a megfigyelő berendezések múködéséról. A képeket legfeljebb egy hónapig lehet megőrizni, kivéve természetesen, ha bírósági nyomozás folyik. A felvett személyeknek joguk van megtekinteni a videokazettákat. A kamerák elhelyezése engedélyhez kötött. Éppen ezen a területen problematikus a garancia. Az engedélyt minden megyében a prefektus adja ki, egy magas rangú köztisztségviselő által elnökölt bizottság véleményezését követôen. Egy független adatvédelmi bizottsággal szemben a prefektus mindig függ a kormánytól és a belügyminisztertől: tehát nem a legalkalmasabb arra, hogy felmérje a közérdek és a személyi szabadság fontosságának mértékét, döntése nem jelenthet garanciát. A törvény bevezetése óta minden bejelentett megfigyelőrendszert engedélyeztek. Aggodalmat kelthet az a tény, hogy a felhasználók nem igyekeznek betartani az új szabályokat. Jelenleg a múködő rendszerek kevesebb, mint 25\%-a van bejelentve.

Láttuk, hogy az ikonikus jel számos sajátsággal rendelkezik a többi ábrázolásmódhoz képest. A többletjelentést hordozó képek miatt nehéz tiszteletben tartani az adatvédelmet. A képekhez való hozzáférés joga egy harmadik személy adatainak védelmébe ütközik abban az esetben, ha csoportról készült felvételről van szó. Ugyanígy nehéz érvényre juttatni a tiltakozás jogát egy géppel szemben, mely soha nem kér engedélyt a felvételre. A kép megmutathatja a felvett személy etnikai hovatartozását, mely igen kényes adat, de védelmét nehezen lehet garantálni. Az ikonikus jel természetéból adódóan nagyon érzékeny, digitalizációja tág teret nyit az illegális terjesztés és a manipuláció elő́tt. Ha nem csupán szimbolikusan szeretnénk az adatokat védeni, hatékonyabb szabályokat kell kidolgozni. Az 1995-ös európai direktíva egyik utolsó cikkelye megfogalmazza, hogy szükséges lenne több figyelmet szentelni a képekbôl és hangokból álló adatoknak, és „olyan törvényekrôl gondolkodni az információs társadalomról folyó kutatások eredményeinek tükrében, melyek szükségessé válhatnak a információs technika fejlődésével". 


\section{JEGYZETEK}

${ }^{1}$ Bordeaux-Talence-i Michel de Montaigne Egyetem, Médiakutató Központ.

2 Ez az előadás az Személyi Adatbiztosok 22. Nemzetközi Konferenciája (Conferenza Internazionale sulla privacy e la protezione dei dati personali) bevezetố részében hangzott el (Velence, 2000. szeptember 28-30.). Az előadás szövege megjelent a konferencia elóadásaiból szerkeszte tr kiadványban.

Az Olasz Adatvédelmi Bizottság honlapja: http://astra. garanteprivacy.it/garante/

\section{IRODALOM}

Ansidei M., „Technologies de surveillance à distance et prévention de l'insécurité urbaine” in Actes du colloque international sur les services de télécommunication, Arcachon, juin 1999; Les risques urbains, Anthropos, 1998.

Auge M., Nonlieux. Introduction à une anthropologie de la surmodernité, Seuil, 1992.

Bauer A. et Raufer X., Violences et insécurités urbaines, PUF, 1998.

Bouióllier D., „Un nouveau maillon controversé de la chaîne sécuritaire: les débuts de la vidéosurveillance à la RATP" in Les dispositifs de sécurité dans les transports urbains, Rapport de recherche Plan urbain, 1995.

Cadoux L., Voix, image et protection des données personnelles, Rapport CNIL, février 1996; Vidéosurveillance et protection de la vie privée, Rapport CNIL, novembre 1993.

Delfour J. J., „La vidéosurveillance dans les lieux publics et ouverts au public: dispositif et application de la loi du 21 janvier 25, Mémoire DESS, Université Paris XIII, septembre 1999.

Elias N., La civilisation des moeurs, CalmannLévy, 1973.

Flaherty D. H., Protecting Privacy in surveillance societies, University of North Carolina Press, 1989.

Foucault M., Surveiller et punir, Gallimard, 1975.

Grevy M., „Vidéosurveillance dans l'entreprise: un mode normal de contrőle des salariés?” in

Droit Social, N 4, avril 1995.

Hanot D., Liberté surveillée, L'Harmattan, 1996.

Heilmann E. et Vitalis A., Nouvelles technologies, nouvelles régulations?, Rapport de recherche IHESI/CNRS, mai 1996. IHESI (Institut de hautes études pour la sécurité intérieure), Actes du comité d'experts, Sécurité et technologies, Paris, juin 1993.

Marx G. T., „La société de sécurité maximale” in Déviance et société, Vol. 12, N, 1988.

Norris C. et G. Armstrong, The maximum surveillance society, Berg, Oxford, 1999.

Ocqueteau F. et Heimann, „Droit et usages des nouvelles technologies: les enjeux d'une réglementation de la vidéosurveillance" in Droit et Société, N 36/37, 1997; Vigilance et sécurité dans les grandes surfaces, IHESI/LHarmattan, 1995.

Poulett Y., „Libertés et société de l'information: le droit de participer et le droit de s'en exclure" in Ubiquité, novembre 1998.

Robert et alii, Les comptes du crime, L'Harmattan, 1995.

Roche S., Sociologie politique de l'insécurité, PUF, 1998; Seuil, 1996. 
Rodota S., Tecnopolitica. La democrazia e le nuove technologie della comunicazione, Laterza, 1997.

Sorrentino V., Il potere invisible, La meridiana, 1998.

Virilio P., „L’eil pour œil ou le krach des images” in Le Monde diplomatique, mars 1998.; La bombe informatique, Galilée, 1998; La vitesse de libération, Galilée, 1995.

Vitalis A., „Vidéosurveillance et protection des libertés individuelles” in Societa dell'informazione tutela della riservatezza, Giuffre, 1998; „Big Brother is watching you” in The Gardian Weekly (The Washington post/Le Monde), september 1998.

Whitaker R., The end of privacy, The new Press, Nueva York, 1999. 